\title{
ON THE STRATEGIES OF MAINTAINING AND TRANSMITTING RELIGIOUS TRADITION WITHIN THE INGRIAN FINNISH SEURALAISET-MOVEMENT
}

\section{Ergo-Hart Västrik}

\begin{abstract}
This essay casts some light on the religious traditions of the IngrianFinnish seuralaiset-movement. This non-institutionalised mystical-ascetic religious movement, which emerged in the first half of the 19th century, was widely known among the Finnish population of the presentday Leningrad Oblast. Both lay and religious authorities made continous endeavours to eliminate the movement and therefore the strategies of maintaining and transmitting their religious tradition in the circumstances of heavy pressure pose great challenges. The essay is based on recent field materials recorded on the Ingrian-Votian expeditions of the Estonian Literary Museum in 2001-2002. Sohvi K., the key informant who lived in Kolpino, was an earnest follower of the seuralaiset-movement and an active practitioner of their singing tradition. Materials of three recording sessions with Sohvi K. allow to discuss the position of the local prophet in the process of mediating the repertoire of the movement, the importance of sound recordings in sharing the religious communion with people who were not able to participate in prayer meetings, as well as the role of handwritten hymnals and photographs in maintaining and transmitting the tradition of the movement.
\end{abstract}

Keywords: ecstatic religious practices, hymn singing, Ingrian Finns, local lay prophets, manuscript hymnals, popular religious movements

\section{INTRODUCTION}

The religious movement, referred to in this article as seuralaiset (meaning in word by word translation 'members of the fellowship' or 'participants of the prayer meeting'), represents the Ingrian Finnish oicotype of the Russian mystical-ascetic religious movement of khristovschina (also called sekta khlystov) which gained great popularity in many gubernias of Russia after the Great Schism at the turn of the 17 th and 18 th century. ${ }^{1}$ Among the characteristic traits of this movement there were certain ecstatic practices (the so-called radenie) that included religious songs, ecstatic dances and manifestations of popular prophesy. One of the centres of the movement at 
the beginning of the 19th century was St. Petersburg, the capital city of Russian Empire, which introduced these practices to the Lutheran Finnish population living in the vicinity of the city. The movement became publicly recognised as the sect of hyppääjät jump$\mathrm{ers}^{\text {'2 }}$ whose teaching spread widely in Ingria and Eastern Finland in the first half of the 19th century as a result of the activities of its leaders.

According to the published sources of the 19th century, Finnish members of the movement called themselves heränneet 'awakened ones', uskovaiset 'believers', or without any advanced specification just as seuraväki or seuralaiset 'participants of prayer meeting', veikot 'brothers' and sisot/siskot 'sisters' (Akiander 1860: 191-192). The movement did not share established teachings as the local groups assembled around charismatic preachers whose apparition-based statements were frequently digressive and therefore their practices contested each other. This variety was vividly described by the people who participated in the movement in the 1830 s-1850s but distanced from it on various reasons soon after. ${ }^{3}$ As leaders of the movement manifested critical attitude towards the teachings of the Lutheran church and many followers abandoned priestly sacraments, their activities attracted attention of the Lutheran clergy. In the middle of the 19th century information about this sectarian community reached the publications intended for Lutheran pastors as well as the Finnish newspapers (see S-s 1856, Ullmann 1857). Reflections concerning the popularity of hyppääjät-movement can be also found in the field notes of folklore collectors who visited Ingria in the 1850s and 1860s in order to record old-type folksongs in Kalevala metre. Several of them reported at the same time of the reluctance of believers to sing older folk songs; on the other hand, folklore collectors emphasized their openness in regard of innovation and education (cf. Niemi 1904: 228-229, 279-280, 300, 368-371, 386-387, 411; Haltsonen 1957: 16, 24, 57).

The first court trials against members of the movement were held already in the 1830s, soon after the formation of the Ingrian-Finnish oicoptype. Seuralaiset were accused mainly of disobedience and sexual exaggerations, which resulted in physical punishment, longterm imprisonment and deportation of their leaders and devoted adherents (see, for example, Akiander 1860: 193-195; Puolanne 1936: 
286-290). Local Lutheran and Orthodox authorities in cooperation with lay officials led the persecutions during the Tsarist period but the movement survived and even resulted larger membership. After the establishment of Soviet anticlerical and atheistic policies in the 1930s many of the believers were deported, which brought along the scattering into smaller dispersed groups. It is evident that since the Soviet repressions the community of seuralaiset did not reproduce itself any more (that is, no new community members appeared) and current members worked for preserving their specific religious tradition. One can say that many endeavours were made to eliminate this non-institutionalised movement in the margins of Eastern and Western churches. Vitality of the movement is highly remarkable as the seuralaiset have been active, without external support, up to the end of the 20 th century. ${ }^{4}$

There are loads of studies dedicated to Russian traditional mystical-ecstatic religious movements, but their Ingrian-Finnish counterparts lack, until now a comprehensive up-to-date survey. ${ }^{5}$ However, the present article is not aimed to fill this gap. It is based on recent field recordings and casts light on some features of a local prayer group movement in the parish of Skuoritsa (Skvoritsa). ${ }^{6}$

\section{THE KEY INFORMANT: CONTEXT OF THE INTERVIEW SESSIONS}

In this article my aim is to observe the religious practices and singing tradition of the seuralaiset as these were presented few years ago by one singular member of this movement. Our key informant in this respect was Sohvi K., an elderly lady of Ingrian Finnish descent who during the recording sessions was living in Kolpino, the satellite town of St. Petersburg.

Our research team visited Sohvi K. for the first time on her 83rd birthday in June 2001. Already during our first meeting, we realised the importance of hymn singing in this particular tradition and were convinced that Sohvi knew well the essential repertoire of the movement. Our key informant could be considered an earnest believer and an active practitioner of the movement's singing tradition despite the fact that for several years there has not been around companions with whom she could exercise the religious practices of 


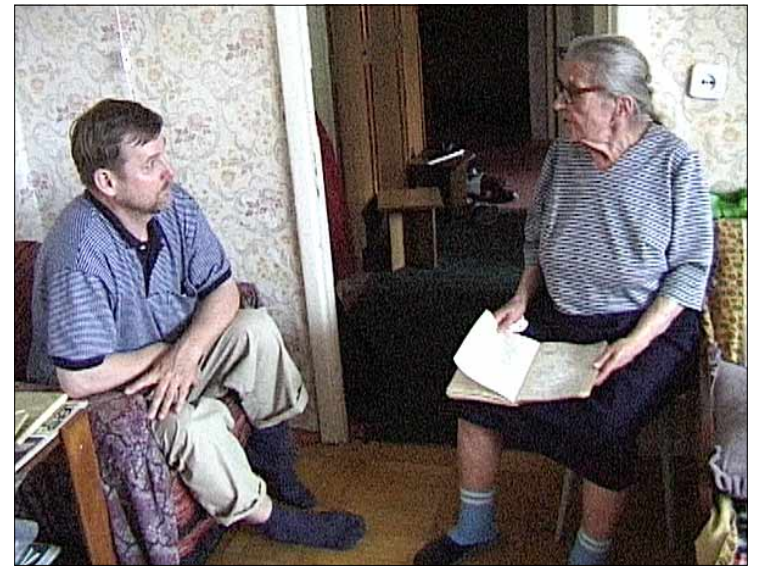

her inherent prayer group. Sohvi's vigorous character and charismatic personality had given her strength to remain faithful to her creed also in the circumstances of being "the only fighter in the battlefield".

The study is based on three interview sessions made by the research team of the Estonian Literary Museum in 2001-2002 at Sohvi's home in an ordinary Soviet-type nine-storeyed block of flats where she lived together with her granddaughter's family. The analysed corpus included six hours of video recordings containing both interviews and spontaneous singing. ${ }^{7}$

The first interview session was carried out under the guidance of Arvo Survo, the local Lutheran pastor of Kupanitsa (Gubanitsy) parish, who had a crucial role in establishing a closer contact with Sohvi as well as in establishing the trustworthy relationship with her for the next meetings. Survo as the initiator of the religious activities in Ingria during the late and post-Soviet period, held considerably high reputation among the elderly Ingrian Finnish women. He had visited Sohvi many times before satisfying her religious needs through joint singing sessions and at the same time learning the songs of the movement. According to pastor Survo, Sohvi had not allowed to make recordings during his earlier visits in the company of scholars. This time Survo's presence, mediation and explanations that we came to learn the singing tradition of the move- 


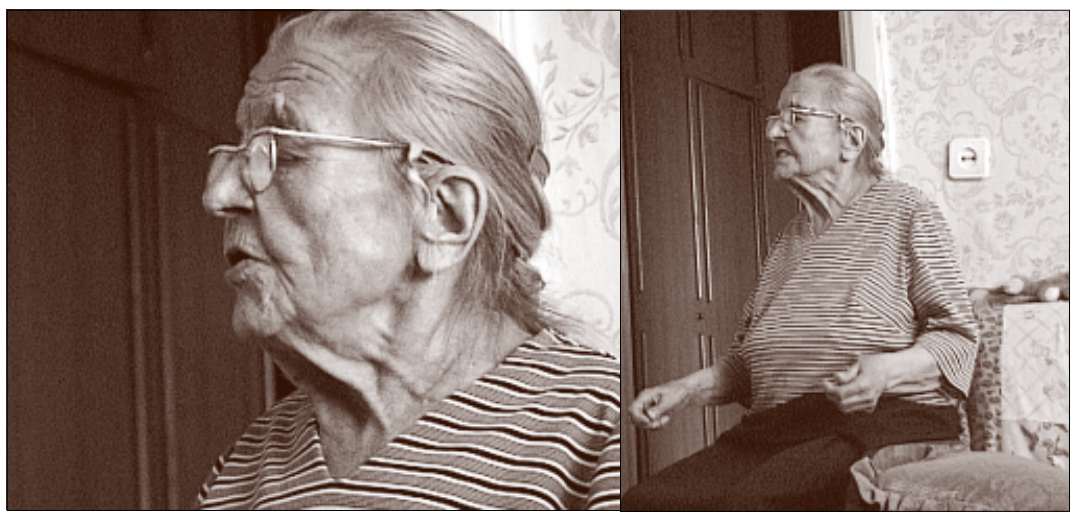

Photos 1 (left), 2-3 (above). Sohvi K. and Arvo Survo singing hymns in June 2001.

ment, made the attendance of outsiders as well as recording possible. Thus, in order to get closer to the inner knowledge of the movement, the members of the researcher group had to take the role of disciples, sharing and presenting also our own knowledge and singing skills. Despite the fact that we explained the motivation of our work for several times, Sohvi remained remarkably cautious while certain subjects were discussed during the interview sessions. Her suggestion was not to ask and urge excessively as human beings should not take too much interest and intervene in godly affairs. According to her words "God knows, but we do not know how to examine those things as this is not our business. The most important thing is that we had faith in our hearts..." (ERA, DV 296, 3). As a consequence, our recording sessions were framed by continuous balancing between our scholarly endeavours and our informant's religious judgements as both parties tried to feel out the boundaries of their interview partners.

Up to our acquaintances with Sohvi we had only come across an outsider's point of view on the movement. Several elderly Ingrian Finnish women with whom our research team worked with in 20002002 remembered the hyppääjät-movement in Central Ingrian-Finnish villages. ${ }^{8}$ Through Sohvi's personality we were able to get acquainted with an insider's point of view on the tradition. Detailed information acquired from Sohvi, enabled us to understand better 
the 19th century descriptions, to get more human-centred (and emic) view on the movement, as well as to follow the dynamics inside the religious tradition.

Many of the minor topics as well as crucial questions remained untouched during our transient interview sessions and unfortunately Sohvi could not answer them later. She passed away few months after our last interview session in 2002.

\section{THE CASE OF SOHVI K.: PORTRAIT OF A BELIEVER}

Sohvi K. was born into the family of seuralaiset in 1918. His father came from Ylä-Purskova (Iulia-Purskaia) village of Skuoritsa parish and mother from Kantola (Kandokiulia) village of Kupanitsa parish, both known as core villages of the movement in Central Ingria. Their family lived in the nearby urban settlement of Taaitsa (Bolshaia Taitsa) where her father owned a shop during the period of the so-called NEP ('the new economic politics') until the Soviet nationalisation campaign of personal property. Their house was one of the largest and wealthiest households in the settlement; according to Sohvi's words, it provided enough space for 50 people during the prayer meetings. She was the eldest of four sisters who were all baptised in the Lutheran church of Skuoritsa. They were brought up in the spirit of the movement, which meant that their connections with parish church remained quite casual ${ }^{9}$ as they did not attend ordinary services on Sundays and church holidays, but held their own meetings where both young people and elderly people gathered. It is evident that Sohvi got accustomed with the traditions and norms of the movement in her childhood.

Sohvi attended the local Finnish school for three years, during fourth year she studied in Russian school and after graduation she entered a trade school in Leningrad where in the course of a year she was trained to become a weaver. Sohvi had to earn her own living at an early age as her mother died in 1930 and father followed her four years later when she was only 16 years old. She became the caretaker of her younger sisters and soon married her husband Paavali (Pavel) K. who was 14 years older than Sohvi. They obviously got acquainted on prayer meetings as her husband was an 
Strategies of Maintaining and Transmitting Religious Tradition

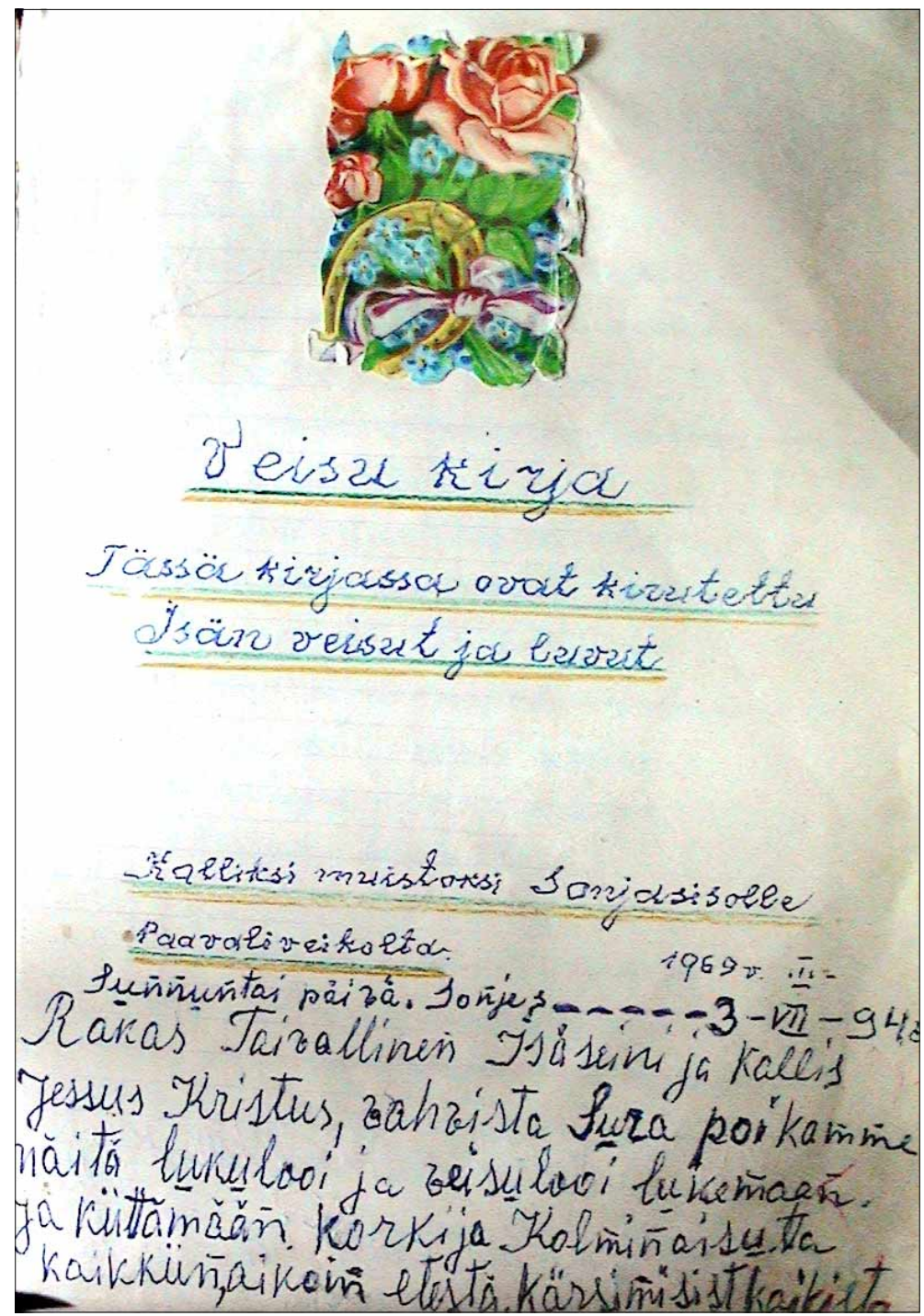

Photo 4. Title page of Sohvi K.'s hymnal with dedication by her husband to Sohvi and her own inscription to their son. 
active member of the same prayer group and felt sympathy for the precocious orphan.

Before the Second World War the family was forced to move to Cheliabinsk where Paavali worked at the steelworks. In 1947 their son was born. After the war and Stalinist repressions, the family was not able to move back to their home area and they settled in Estonia where they lived in the littoral town of Pärnu for six years. From there they returned to the Leningrad District where Paavali worked as a highly valued accountant almost to the end of his life in 1973. Sohvi continued to work as a weaver and lived after the death of her husband with her son's family and later with her granddaughter's family.

It is evident that Sohvi was an active member of the movement throughout her life. She was enculturated into the worship community at an early age and the religious life provided her a wider social network, laying foundation to the specific self-identification as well as boundaries between "true believers" and outsiders (the 'worldly people'). In our third interview Sohvi stated, for example, that she wanted to live freely and therefore refused to become a member of Soviet youth organisations (pioneers, Komsomol). The need for social interaction was satisfied with devoted and close relationships within the prayer group. Besides many other features this was reflected in calling female fellows siskot/sisot 'sisters', male fellows veikot 'brothers' and the religious leaders respectively isä 'fathers'. While referring to the members of the prayer group Sohvi used Finnish vernacular forms of first names. In case of "sisters", the respective word in Ingrian Finnish dialect siso, was attached in her usage so firmly to the proper name that it formed a kind of derivational suffix -(s)soo (for example, Katiassoo, Hedussoo, Liisbetssoo, Marissoo). Sohvi described the religious community as a big family and thus in some cases it was even difficult to understand when she was speaking about her own sisters and when about the other members of the prayer group.

During the Soviet period the local prayer group scattered into smaller groups but the religious practices were exercised also among those who had to move to far-away regions. Prayer meetings were held less systematically, when members of the movement happened to come together. The meetings were drawn into 
private sphere, as one's religiosity could not be exposed in public. The number of people who gathered to the meetings at that time was considerably smaller compared to that of Sohvi's adolescent memories from the 1930s. Under new conditions of conspiracy the members of prayer group were not able to hand on religious traditions to their offspring. ${ }^{10}$ This concern was illustrated in the title page of Sohvi's manuscript hymnal (see Photo 4) where she expressed her desire for continuity: "Dear Heavenly Father and Jesus Christ, give strength to our son Sura to read these prayers and hymns".

The fact that prayer meetings were held within smaller groups of believers in the 1970-1980s was vividly verified by the extensive set of sound recordings at Sohvi's possession. ${ }^{11}$ These recordings reflect the particular need inside the movement to document and maintain tradition using modern technological means. This routine also had a practical side. The recordings allowed those members of the prayer group who were not able to participate in the meetings to listen to the prayers and singing. In recent years, when Sohvi's capacities for social interaction with other members of the prayer group were scarce she practiced singing with a tape recorder. Earlier recordings of the prayer meetings enabled her to follow the ritual "in spirit" and (re)experience the religious joy and spiritual communion repeatedly and regularly. This kind of practice, which combined religious tradition, performance and technological means, helped her to keep the religious repertoire of the movement in active use.

In addition to the recordings of the prayer meetings, Sohvi listened to the tapes recorded by his fellow-member Mikkeli Haukka (Mikhail Gauka, 1913-1997), from the village of Korkkylä (Kurgolovo), who lived in Sweden after the Second World War. In emigration he had recorded a selection of movement's singing repertoire with an accompaniment of banjo, as well as prayers on compact tapes and sent them behind the "iron curtains". During our interview sessions we realised that Sohvi extensively practised singing while listening to the recordings of Mikkel-veikko who was attributed the role of the fellow-singer. 


\section{HYMNS REVEALED BY THE HOLY GHOST}

Relatively detailed information about the singing tradition of the seuralaiset-movement dates back to the middle of the 19th century. An anonymous informant of Matthias Akiander (1860: 176, 177) mentioned in his description from the year 1856 that in addition to singing from ordinary Lutheran hymnals and other printed collections of spiritual songs, the adherents of the movement used to sing also specific henken veisut 'hymns of Spirit', which might have lasted even for several hours during prayer meetings. The verse lines of these songs were first sang by the lead singer and then repeated by the prayer group. The author of the description referred with this term to the spiritual songs, which were acquired via divine revelation (intervention of the Holy Ghost) and could be divided into two groups: 1) spontaneous songs based on instant revelation mediated by the singer in the very moment of revelation during the prayer meeting; 2) songs that were written down (textualised) by the person who experienced revelation while being alone and later performed during the prayer meeting (ibid.: 179). Akiander's informant mentioned the scarcity of those people who could mediate revelation of the Holy Ghost spontaneously. Songs of the second type were better known within the movement and handwritten texts of the songs were widely spread and memorised. Popularity of these songs was illustrated by six examples, which were added at the end of the description (ibid.: 195-203).

Above-mentioned spiritual songs, "hymns of Spirit", had an important role also in Sohvi K.'s repertoire. To refer to these songs she used the emic term pitkät veisut ('long hymns') and attributed their authorship - or, in fact, the role of mediator - to the local "prophet" Mikkel-veikko ('Brother Michael') from the village of Purskova. ${ }^{12}$ Below is the quotation from the interview session with Sohvi where she explained us for the first time the role of the prophet in the process of composing these songs:

Interviewer: But who mostly composed those hymns?

Sohvi: You see, the father who was mentioned in this hymn, [reciting the verses] "to him the Spirit appeared, / the Holy Ghost addressed, I secretly He said”. You see, this Mikkel-veikko from Purskova wrote all of them, he wrote all those hymns... He was jailed in Miitava for two years. 
Interviewer: Did this happen during the Tsarist or the Soviet period?

Sohvi: No, he was there in 1900.

Interviewer: So, he was put in prison in 1900...?

Sohvi: There were the pastors of the [Lutheran] church of Skuoritsa... In the church of Skuoritsa one of the pastors was good, but the other one couldn't tolerate these seuralaiset who attended [prayer meetings], who did not come to his church, did not bring their money there, but attended their own meetings. You see, those he didn't love, he didn't like them, yes. And you see, this was the pastor of Skuoritsa church who put him [in prison], he who wrote all those hymns... Even now I think that for this reason it is not possible to repair the church of Skuoritsa. It has been left un-repaired, you know, what a bad shape it is in. I think that it is probably for this reason that they whipped Mikkel-veikko, in the cellar they flogged him with whip several times...

(ERA, DV 276, 16 [0:06:06-0:07:55]).

Mikkel-veikko, alias Mikkel Soini, was a historical person who lived in 1839-1920. He was the charismatic leader of the local prayer group and, according to Sohvi, wrote down alltogether 38 "long hymns", which made up the core repertoire of their prayer group. Songs of Mikkel-veikko, revealed to him by the Holy Ghost, had a significant position in the "liturgy" of the prayer meetings, as while singing these songs, specific ritual practices were exercised that lead the participants to a trancelike state of consciousness. Sohvi repeated the story concerning the divine origin of the long hymns for several times in all interview sessions, which indicates the importance of revelations, the role of the religious leader and particular ritual practices in her religious world view.

Interviewer: Did he compose then the majority of these songs, not all of them...?

Sohvi: These long hymns, all of the 38 long hymns he [created] by himself.

Interviewer: He created all of them by himself?

Sohvi: All of them! He didn't compose by himself but the Holy Ghost [came to] him. He had these moments at that time because of the Holy Ghost. [These] came into his heart, he wrote and wrote and wrote, what the Holy Ghost told him he wrote. After 


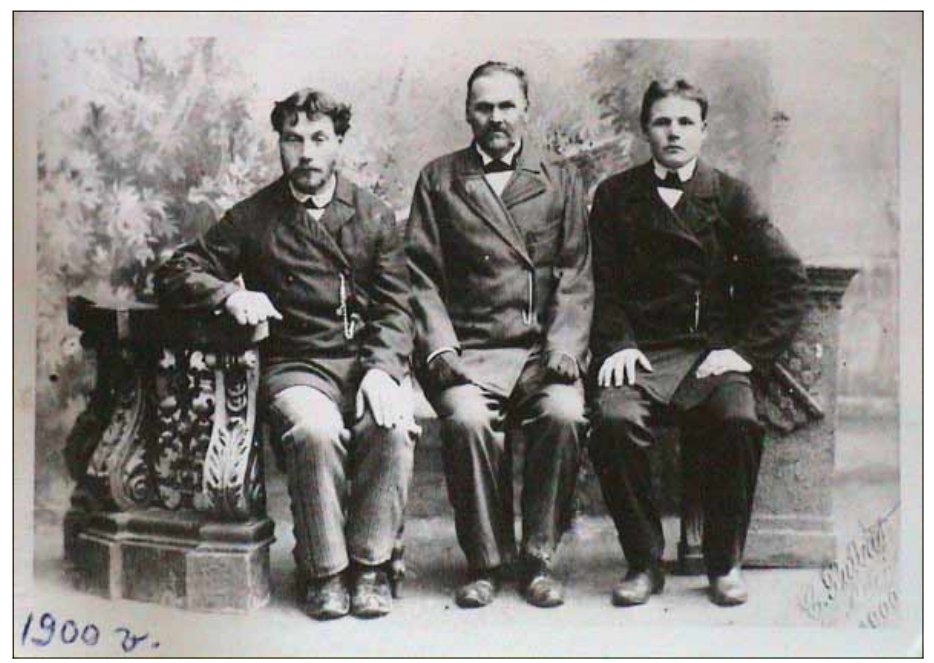

Photos 5 (above) and 6 (right). An old photograph depicting the prophet Mikkelveikko and two members of the prayer group in Miitavi. (Front and back side of the photograph.)

all, there are many, many hymns are like these: "Welcome, You Holy Kin", this "O Delightful Land of Father", "Now I Start the Journey", "In the Wilderness", "On the Mount of Faith", many hymns all in all.

(ERA, DV 276, 16 [0:09:40-0:10:25]).

Interviewer: But your husband, from where did he write these songs?

Sohvi: He was born in 1902, and at that time perhaps the prophet wrote these songs by himself. He who wrote these songs, yes, did it through the Spirit. You probably do not understand how this [worked] through the Spirit, how the human being... how it came... it was given to him, to the prophet, through the Holy Ghost. So he didn't write [these songs] from anywhere but he wrote them by himself. Words came to his mouth and [he] wrote on paper what the Spirit brought him. He wrote all this on paper and then everybody, sisters or brothers, wrote [these songs] to themselves. 


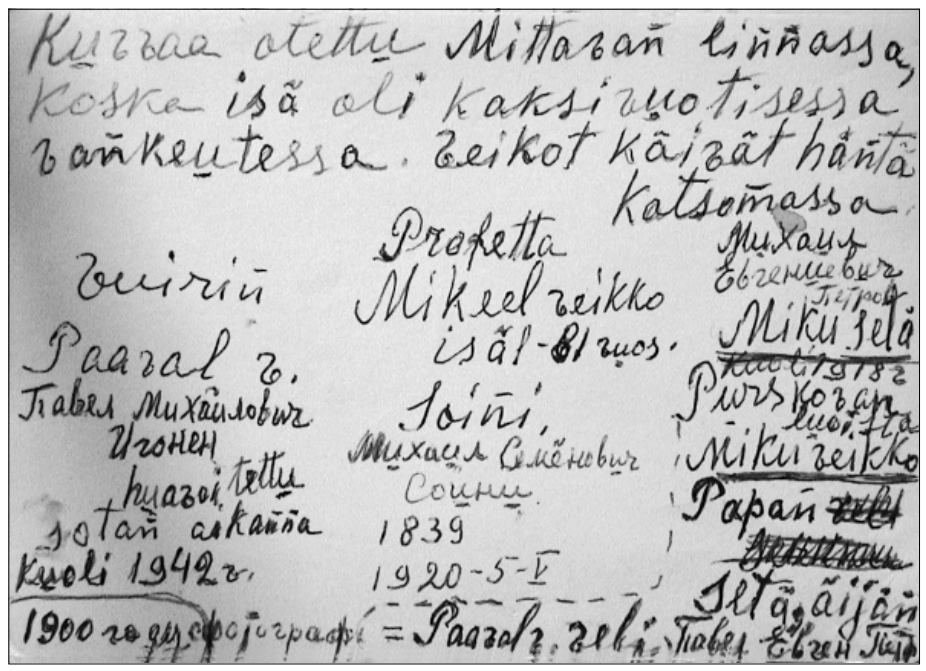

(ERA, DV 278, 3 [0:11:20-0:12:06]).

It is evident that Sohvi mediated the group-lore maintained by and transmitted within the prayer group, though she never met the prophet. We could realise that Mikkel-veikko as one-time elder of the local group had in Sohvi's religious microcosm the status of "a culture hero" who obviously had established a new epoch in the life of that particular religious community. Important dates of his life course and memorable deeds were highly mythicised. Sohvi's stories made up a prophet's vita, essential parts of which were the writing of the hymns through revelation of the Holy Ghost, persecutions by the pastors of Skuoritsa church and imprisonment in Miitava (Mitava) ${ }^{\mathbf{1 3}}$ in 1900-1902. She had even built up a personal chronology, which extended to the present moment of time. For example, during our first interview session Sohvi mentioned that Mikkel-veikko lived for 81 years and that in summer 2001 exactly 81 years had passed since his death in 1920 (ERA, DV 276, 16 [0:08:58ff]). She also admitted that Mikkel-veikko was not the only prophet but there were "fathers" before and after him.

During our third interview session we realised the important role of photographs in the process of memorising and textualising the stories (information) concerning the prophet Mikkel-veikko. In 

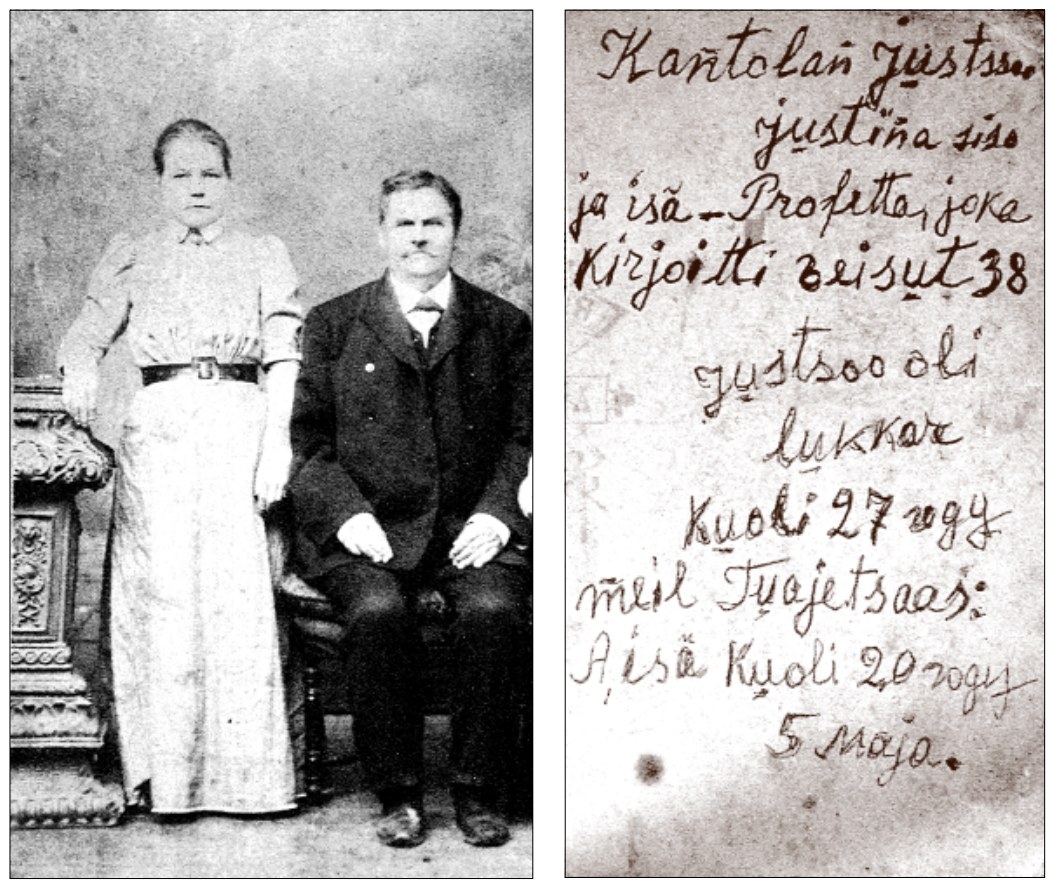

Photos 7-8. An old photograph depicting prophet Mikkel-veikko and the lead singer Justssoo. Front and back sides of the photograph.

Sohvi's possession there were several old photographs about the prophet, which she had probably inherited from her parents. According to the detailed inscriptions on the other side of the photograph one of them represented Mikkel-veikko and two members of the prayer group when the latter came to visit their leader in jail (see Photos 5-6). The inscription was written partly in Finnish and partly in Russian containing also biographical information about the persons photographed (punctuation marks added by me-EHV):

The picture was taken in the castle of Miitava as the father was in imprisonment for two years. Brothers went to visit him. [From left to right:] Paaval-v[eikko] from Vuiri [Vyra] settlement, Pavel Mikhailovich Igonen, buried during the war, died in 1942. Prophet Mikkel-veikko Soini, father lived 81 years, Mikhail Semenovich 
Soini 1839-1920-5-IV. Mikhail Evgenevich Petrov, Uncle Miku, Miku-veikko from Purskova, died in 1918 from a bullet, papa's uncle, grandfather Paaval v[eikko]'s brother, Pavel Evgen[evich] Petr[ov]. Photographed in 1900.

Another photograph depicted the prophet Mikkel-veikko and the lead singer (precentor) Justssoo (Justina-siso 'Sister Justina') from the village of Kantola. Inscription of this photograph was informative, too (see Photos 7-8): "Justssoo, Sister Justina from the Village of Kantola and father, the prophet who wrote 38 hymns. Justsoo was a lead singer, died in [19]27 in our house in Taaitsa. But father died in [19]20, on the 5th of May".

The texts on the photographs largely overlapped with the core motifs related to the prophet, which were mentioned during the first interview session (at that time the photographs were not presented). Significant are the parallel forms of the names of the people depicted. Analysing the composition of the inscription and different pencils used it is evident that Sohvi had initially written the names of "brothers and sisters" as they were used within the religious community (Paaval-veikko, isä Mikkel-veikko, Miku-veikko, Justssoo), and had later added their official names (in Cyrillic) as well as details about the end of their life. One of the men depicted on the first picture was Sohvi's granduncle whose connection with the writer was established through mentioning her grandfather's name. In all probability Justssoo was also among Sohvi's close relatives as she came from the same village as Sohvi's mother and died in their house.

\section{THE MANUSCRIPT HYMNAL AND SINGING WITH TAPE RECORDER}

As the movement of seuralaiset was never officially institutionalised, the local prayer groups neither had fully canonised religious repertoire nor a printed hymnal. Sohvi kept with ultimate care the massive manuscript hymnal that was written by her husband and dedicated to Sohvi in 1969 (see the votive text on the title page of the hymnal on Photo 4: "In precious memory to Sonja-siso from Paavali-veikko"). ${ }^{14}$ 
All the above-mentioned thirty eight "long hymns" were included in the hymnal where they occupied the first 154 pages and evidently the most important position. The rest of this voluminous manuscript comprised of diverse religious texts (for example, confession of faith, prayers, excerpts from the Bible) and a variety of songs referred to by Sohvi with emic term lyhyet veisut 'short hymns'. The category of "short hymns" contained a wide selection of spiritual songs from Psalms, Lutheran hymnal as well as songbooks (for example, "Zion's Zither") of Evangelical movements, including also few texts in Russian. ${ }^{15}$

Compared with that of the long hymns the short hymns had a different function within the prayer meetings. They were sung at the very beginning and at the end of the meeting, sometimes also between preachings, marking the transitions from one part of the ritual to another (cf. Suojanen 1984). Sohvi described the overall arrangement of a prayer meeting during our second interview session while commenting the content of her hymnal.

Interviewer: And in addition there are those short hymns? Sohvi: Then comes, the reading is given, confession of faith, and whatever there are... The first reading and hymns from Psalms. We had the psalms... When the prayer meeting was started then in the beginning the long hymns were not sung. At the start psalms were sung from the Psalm Book. [---] You see, when the lead singer - it was still called a precentor - sang a short hymn, then the prophet started to preach. And if preaching was done, several preachers did their preaching, then lastly they started to sing long hymns. And then they started to move!

(ERA, DV 278, 3 [0:13:16-0:14:23]).

This sequence, the alternation of songs and preaching could be followed on the recordings at Sohvi's possession and the same concerned, with some reservations, the descriptions of prayer meetings from the first half of the 19th century (cf. Akiander 1860: 172179). In general, the prayer meetings had quite a loose structure but evidently the culmination was reached with "long hymns", which were performed together while moving in a circle. The tempo of singing and moving gradually increased,which helped the participants to reach the religious excitement manifested in loud shouts 
of joy and "jumping" interpreted by the participants as an evidence of the emergence of the Holy Ghost (referred to with phrases tulla henkee 'to come into spirit' or olla henkess 'to be in spirit').

For several times Sohvi stressed the idea that in earlier times (in her childhood) hymns were sung by heart during prayer meetings. Written texts were not used in the course of the meetings as the lead singer started the songs and usually all the verses were repeated, which eased the singing and learning for those who were not so familiar with songs. This kind of practice was apparently rooted in the requirements of ritual as the exercised collective technique of ecstasy, including moving and "jumping", did not predispose the use of hymnals. In addition, one can assume that singing by heart might have been conditioned by the need for conspiracy. Consequently, Sohvi refers to the type of transmission that combined both oral and written, which was characteristic to religious folklore of the 19th and 20th century in general (cf. Panchenko 2002: 271).

During three interview sessions Sohvi sang altogether
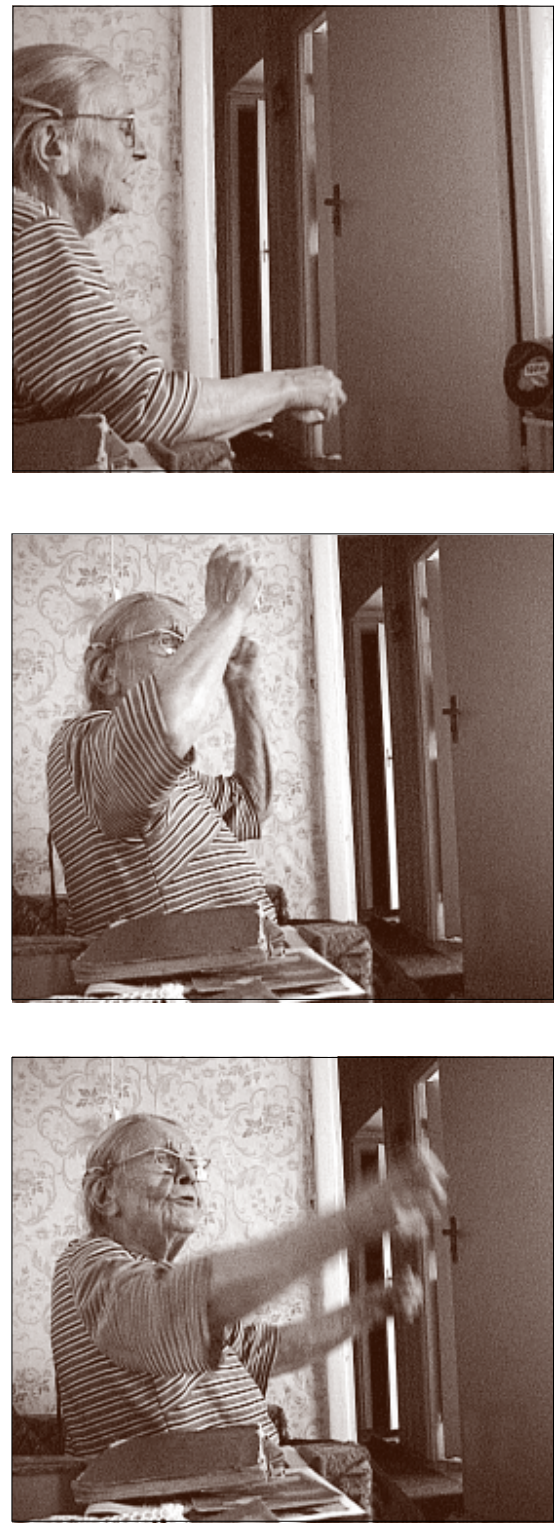

Photos 9-11. Sohvi K. performing the hymn "I'll Sing Hymns in My Worldliness", marking the places where to jump. 
fourteen "long hymns". These performances can be divided into three groups according to the conditions (and specific features) framing the performing events.

Firstly, as the singing situation was initiated by us, the researchers, Sohvi aimed to demonstrate a variety of movement's singing repertoire. For example, she started the first hymn "Oh Delightful Land of Father" spontaneously in order to show the specific mode of singing (each verse line was repeated) and emphasise the unusual length of the songs (many hymns lasted for 10-15 minutes) compared to that of "short hymns". Similarly, while discussing the movement's ritual practises related to the human life cycle, Sohvi introduced an excerpt of the hymn "Now I Start the Journey" that was usually sang during funerals.

Secondly, Sohvi performed the hymns that she herself had chosen with the aim of teaching particular songs to us as disciples. From the corpus of "long hymns" she selected the shortest one available, "Meeting of the Congregation", that contained less characteristic features of the movement's religious worldview.

The third set of songs was the largest, comprising the hymns that Sohvi performed with the tape recorder. Her favourite "singing partner" was the above-mentioned Mikkeli Haukka who had recorded a selection of "long hymns", with an accompaniment of banjo. It is evident that Sohvi had practised singing with tape recorder for a longer period of time following the sequence of prayer meeting and reaching the ecstatic mood while singing. This was convincingly illustrated during the performance of the hymn "I'll Sing the Hymn in My Worldliness" (see text of the hymn in Appendix). Sohvi started to wave her hand to the rhythm of the song while singing and marked the places where people started to "jump" (see Photos 9-11).

Analysing the text of the performed hymns one can point out to the motifs that are typical to the repertoire of the movement of seuralaiset and widely accepted by its Russian counterparts (see, for example, Panchenko 2002: 290-297). The central motif concerns sailing a war ship on the dark and dangerous worldly sea. Members of the prayer group are depicted as the chosen people sailing on the sea in the company of Christ. Jesus's divine power helps the seuralaiset to overcome storms and disasters and reach 
the Heavenly Kingdom. The hymn presented in the Appendix also contains the description of ritual practices including shouting, moving in circle and jumping.

Sohvi herself knew by heart a great number of hymns and even answered during our conversation using passages of the song texts. She had found "scripts" for her life from these hymns and she spontaneously inserted the excerpts of hymns into her answers.

Interviewer: But was it said that the prayer group is like a ship? Sohvi: A ship? Indeed! [Reciting the verses:] "I am singing the hymns in my worldliness / in our King's warship" - one sings this "I am singing the hymns in my worldliness" while sailing the sea. This is, how to put it, this is a spiritual ship. Yes. The one who is faithful is inside that spiritual ship. [Reciting the verses:] "Souls are jumping in joy, I shouting in force of Spirit, I when Jesus welcomes the brother, I our hearts will roar with pleasure. / Whole heaven is delighted, I and rejoices in love, / if we celebrate this / with our pure hearts, / praise the Holy Father and Son, / keep our union, / carry the Holy Cross, / devote ourselves to Him, / worship the Cross, / yet praise in hardships." You see. [Reciting the verses:] "In the spiritual ship / you are half-way in heaven", this is said in the hymn: "In the spiritual ship / you are half-way in heaven. I Souls are jumping in joy, I shouting in force of Spirit, / when Jesus welcomes the brother, / our hearts will roar with pleasure".

Interviewer: But why was it referred to as a war ship?

Sohvi: One said that it is spiritual war if you fight with worldly people, who are against you.

(ERA, DV 269, 1 [0:30:31-0:32:15]).

\section{CONCLUSION}

Seuralaiset were never institutionalised and therefore they can be considered to make up a grass root-level popular religious movement, which maintained and transmitted its tradition with the help of both oral and written means of communication. The tradition and teaching of seuralaiset was shared by literate and more well-todo urban (or semi-urban) as well as rural population. Several traits indicate that the movement originated from urban settings from 
where it was mediated to the rural environment. The life history of Sohvi K., the key informant of the present article, convincingly reflected the same pattern as her family members represented both semi-urban and urban professions and life conditions.

It is evident that the Russian mystical-ascetic movement of khristovchina played a crucial role in the emergence of this religious movement among the Ingrian Finns, and the international atmosphere of the former capital St. Petersburg eased the process of transcending the language and confessional borders. ${ }^{16}$ On the other hand, the characteristic traits of the movement were adapted into the wider context of the Ingrian-Finnish popular culture where it maintained vitality for a longer period of time than its Russian counterparts. We can speak about the Ingrian Finnish oicotype of this particular religious movement with its own peculiarities and a variety of further developments.

The recorded interviews with Sohvi K. enable us to understand better the 19th century descriptions on the topic and follow the dynamics of the developments inside the movement. One of the peculiar traits of the movement was to congregate around local charismatic leaders, the prophets, who framed and complemented the tradition of the local prayer group according to the "godly revelations". Mikkel-veikko, the local prophet from the Purskova village of Skuoritsa parish, appearing in the interviews with Sohvi K., well suits to illustrate this phenomenon. Significant attention was attached in the interviews to the prophet's role as the mediator of the core repertoire of the local prayer group. This idea evidently occupied an important place in the religious world view of Sohvi K. and emphasised the need to maintain and transmit the religious tradition.

The case of Sohvi K. indicated the importance of photographs in the process of textualising and memorising religious lore. The significance of handwritten hymnals had increased under circumstances of dispersing the tradition. The strategies of maintaining and transmitting religious tradition among seuralaiset under the heavy pressure included also recording of the prayer meetings and the core repertoire of the movement. These means of modern technology enabled to share the religious communion with the believers in far- 
away regions and allowed single persons with little social interaction to remain "active practitioners" of the religious tradition.

\section{Acknowledgements}

The fieldwork in Ingria was supported by the grant of the Estonian Science Foundation (No. 4939). Library research at the University of Helsinki in April 2003 was supported by the CIMO Baltia-scholarship. I am indebted to Arvo Survo, Nina Lavonen and Taisto Kalevi Raudalainen for their help in studying the tradition of seuralaiset movement.

\section{Comments}

${ }^{1}$ On the genesis of hristovschiny and khlysty (Russian khlestat' 'to whip') see, for example, Clay 1985, Clay 1988, Panchenko 2002. The latter contains a detailed survey on the historiography of the question on pp. 14-43.

${ }^{2}$ As stated by A. Panchenko (2001: 47) these were probably Orthodox missionaries who coined the pejorative Russian term skakuny 'jumpers' (Russian skakat' 'to jump'), which was later taken over also by the BalticFinnish population. Finnish scholars widely use the term hyppyseuralaiset to refer to the movement. Yet, the author of the present article prefers the emic term seuralaiset in this context.

${ }^{3}$ See, for example, Akiander 1860: 146-164, 171-206, 216-236, 248-268, which contains testimonies of his correspondents from the years 18411856. In 1864 Akiander published also the objection written by Juhana Rontu, the leader of the seuralaiset-movement in Eastern Finland.

${ }^{4}$ According to the recent field data elderly congregation members have held small-scale prayer meetings even as late as in the 1990s.

${ }^{5}$ The latest voluminous works on Russian movements include, for example, Etkind 1997 and Panchenko 2002. A thorough study on the genesis and fate of the ecstatic movement of Ingrian-Finnish castrates (leikkaajat, cf. Russian skoptsy) has been put together by a Finnish folklorist Nina Lavonen which will be published by the Finnish Literature Society (from personal communication in April 2003).

${ }^{6}$ Finnish toponyms of Ingria are used in the article. The present-day Russian place-names are added in brackets.

${ }^{7}$ The research team included Madis Arukask, Taisto Kalevi Raudalainen and the author of the present article. Field recordings, as well as photo- 
graphs shot and copied during the interview sessions, are kept at the Estonian Folklore Archives (ERA, DV 274-278, 295-296).

${ }^{8}$ We recorded a variety of stories with a stereotyped plot related to the ecstatic religious practices of the movement and stigmatised behavioural patterns of the leaders. See, for example, Raudalainen \& Västrik \& Lintrop 2001.

${ }^{9}$ After official baptising in the Lutheran church, children were blessed by the leader of the local prayer group.

${ }^{10}$ Finnish folklorist Päivikki Suojanen (1984: II), studying the hymn singing among Finnish Evangelical-Lutheran revival movements, has paid attention to the fact that the revival movements of the 20th century were chiefly handed on from parents to children within family traditions.

${ }^{11}$ It was not possible to get a thorough overview about the total volume of the recordings. Sohvi's "sound archive" consisted of open reel tapes and compact cassettes. The research team was able to copy two of the cassettes that contained recordings of the prayer meetings held in the mid1980 s.

${ }^{12}$ In order to refer to Mikkel-veiko she used, in addition, the names is $\ddot{a}$ 'father', prohveetta 'prophet', Purskovan-Mikko 'Michael from the village of Purskova', etc.

${ }^{13}$ In German Mitau, in Latvian Yelgava.

${ }^{14}$ The role of handwritten hymnals among the Ingrian Finnish population during the period of Soviet anti-religious policy should not be underestimated and provides an interesting topic for further research projects. Cf. for example, digital copies of the hymnals at the Estonian Folklore Archives (EFA, AK 522-526).

${ }^{15}$ The quantitative analysis of these songs (and the handwritten hymnal as a whole) was not possible during the interview sessions. This exceptional hymnal at the possession of Sohvi's granddaughter is indispensable source for further studies on the repertoire of seuralaiset.

${ }^{16}$ Parallel developments of religious "revival" took place in many countries in the Baltic Sea region at the beginning of the 19th century (cf., for example, Põldmäe 1935, Heino 1976, Suojanen 1984, Plaat 2001). 


\section{References}

Akiander, Matthias 1860. Springarsekten. Historiska Upplysingar om Religösa rörelserna $i$ Finland $i$ äldre och senare tider. IV Delen. Helsingfors: Kejserliga Alexanders-Universitet, pp. 130-206.

Akiander, Matthias 1864. Muutamia tietoja Inkerinmaan sekä Itäsuomen lahkolaisuuksista. Helsinki: J. Simelius'en perillisten kirjapaino.

Etkind, Aleksandr 1998. Khlyst: sekty, literatura i revoliutsiia. Moskva: Kafedra slavistiki Universiteta Hel'sinki.

Clay, Eugene 1985. God's People in the early eighteenth century. The Uglic affair of 1717. Cahiers du monde Russe et Soviétique. Vol. XXVI (1), pp. $69-101$.

Clay, Eugene 1988. The Theological Origins of the Christ-Faith [Khristovshchina]. Russian History / Historie Russe, Vol. 15. No. 1, pp. 2141.

Haltsonen, Sulo 1957. Runoretki Inkeriin v. 1953: lisätietoja D. E. D. Europaeuksen runokeruun historiaan. Suomi, 107: 4. Helsinki: Suomalaisen Kirjallisuuden Seura.

Heino, Harri 1976. Hyppyherätys - Länsi-Suomen rukoilevasuuden synnytäjä. Suomen Kirkkohistoriallisen Seuran toimituksia, 99. Helsinki: Suomen Kirkkohistoriallinen Seura.

Niemi, Aukusti Robert 1904. Runonkerääjiemme matkakertomuksia 1830-luvulta 1880-luvulle. Helsinki: Suomalaisen Kirjallisuuden Seura.

Panchenko, Aleksandr 2001. "On de i mnogikh delal skoptsami... dlia togo, chtob skopit' tsarstvie bozhie": antiseksual'nost' v russkoi narodnoi kul'ture. Mifologia i povsednevnost': Gendernyi podkhod v antropologicheskikh distsiplinakh. K. A. Bogdanov \& A. A. Panchenko (Comp.). SanktPeterburg: Aleteiia.

Panchenko, Aleksandr 2002. Khristovshina i skopchestvo: fol'klor $i$ traditsionnaia kul'tura russkikh misticheskikh sekt. Moskva: Obiedinennoe gumanitarnoe izdatel'stvo.

Plaat, Jaanus 2001. Usuliikumised, kirikud ja vabakogudused Lääneja Hiiumaal: usuühenduste muutumisprotsessid 18. sajandi keskpaigast kuni 20. sajandi lõpuni. Eesti Rahva Muuseumi sari, 2. Tartu: Eesti Rahva Muuseum.

Puolanne, Yrjö 1936. Hyppääjälahkosta Valkjärven seurakunnassa. Suomen Kirkkohistoriallisen Seuran vuosikirja XV-XVIII (1925-1928). Jyväskylä.

Põldmäe, Rudolf 1935. Taevakäijad. Kaleviste mailt. Õpetatud Eesti Seltsi Kirjad III. Tartu: Õpetatud Eesti Selts, pp. 123-176.

Raudalainen, Taisto Kalevi \& Västrik, Ergo-Hart \& Lintrop, Aado 2001. Üksi olles oled üks. Videodocument. Tartu: Eesti Kirjandusmuuseum.

S-s. 1856 = Inkerinmaan suomalaisista heränneistä. Suometar, No. $5-6$. 
Suojanen, Päivikki 1984. Finnish folk hymns singing: study in music anthropology. Tampere: University of Tampere, Institute for Folk Tradition.

Ulmann, C. C. 1857. Die Springersekte in Ingermanland. Mittheilungen und Nachrichten für die evangelische Geistlichkeit Russlands. 13 Band. Jahrgang 1857. Dorpat, pp. 197-209.

\section{APPENDIX}

Veisaan täällä ajassa

Kuninkaamme laivassa, Meren päällä soutaissa, Kotomaalle kulkeissa.

Katsoin uskon vuorella, Näkkyy tuolla puolella

Isän maa viel ihana Yli meren mäntävä.

Sinne tahton vajeltaa, Päässä rauhan satamaa. Vaik' on vaivoin takanna, Kuitenk' on se oma maa.

Se on meille annettu, Ennen aikoi aivoittu,

Pyhilt isilt luvattu, Uhrin kautta kuvattu.

Loppumatoin elämä, Loppumatoin kunnia!

Se on ijät pysyvä, Jos on Isä Jumala.

Sil ei ollut alkuva, Tule ei koskaan loppuva, Eikä aikoin lukua, Yöt'ei päivää kuulukkaa.

Täällä ajat muuttuvat, Niin kuin virrat juoksevat, Viimein poisi katoopi, Koska aika joutupi.
I am singing the hymns in my worldliness

In our King's warship, Rowing on the worldly sea, Rambling to the homeland.

I looked down from the mount of faith, I could see on the other side The marvellous land of our Father Lying over the worldly sea.

I want to go there as a pilgrim, To reach the port of peace, Although it lies behind the hardships, It will still be my own land.

It was given to us,

Foreknown before the foundation of the world,

Promised by the holy fathers, Brought to light through the sacrifice.

Oh, eternal life,

Oh, eternal glory!

It should last aeons,

If our Father is truly the God.

There was no beginning, And there will be no end, There is neither time to be counted, Nor alteration of day and night.

The times are changing here, Flowing like streams, Passing away at last, As the day of judgement will come. 
Sen tähten mun sieluni, Sen tähten mun henkeni Ikävöipi taivahen, Matkal suostu vaivahen.

En mie huoli vaivoista, En mie henkist pahoista, Vaik he vastaan sotivat, Vihaisinna olevat.

En mä huoli sotista, Tahton päässä kotia, Isän maa jo näkyypi, Vielä sotii täytyypi.

Kantaa Herran haavoja, Kärsii ajan vaivoja

Sota laivas soutaissa, Kaanain maalle kaallaissa.

Purjehtimme merellä, Jessus souta etellä, Hän on laivan haltijas, Enkelit on vartian',

Ettei laiva hukkuisi, Allot maahan kaataisi, Koska myrskyt nousevat, Meren aallot pauhaavat.

Silloin purjet nostamme, Uskon mostit laitamme, Kysymme laivan haltialt, Luojan Kaikkivaltialt.

Kyl' hän tuulet asettaa, Meren aallot seisauttaa, Herran Henki puhaltaa Vaik' oisi monta tuhatta, Jotka tuulta nostaisiit Sottii kansain tahtoisiit Hän ne kaikki voitaapi

Kosk' hän kansamme soutaapi.'Cause He will row with us. To our Lord Almighty.
Therefore the soul of mine, Therefore the spirit of mine Is yearning for the heaven, Is acceding to the hardships of the journey.

I will not care about the hardships, I will not care about the evil spirits, Though they fight against us, Though they look rather angry.

I do not care about the struggles, I want to reach my true home, The Father's land is in my sight, I have to struggle on.

To carry the stigmata of my Lord, To suffer the hardships of my worldliness,

Rowing in the warship, Drifting to the land of Canaan.

We are sailing on the worldly sea, Jesus is rowing far ahead, $\mathrm{He}$ is the owner of the ship, Angels are the guardians,

Protecting the ship from sinking, Keeping it from the crushing waves, As the storms will arise, Waves of the sea will roar.

Then we put up the sails And raise the mast of faith, We pray to the owner of the ship,

He will calm down the winds, Will put down the waves of sea, The spirit of Lord will blow, Although there are thousands of them,

Who are raising the wind, Who are willing to fight with us, He will win all of them, 
Kyssyy merimiehiltä, Kyssyy niiltä veljiltä, Jotka laivaa hallitsoot, Sota laivaa hankitsoot:

"Mitä veljet pelkäätte, Kun merellä riennätte? Olkaat rauhas pyhässä, Mie uon kanssan' sotassa!”

Sitten käskyn antaapi, Sekioitan lentääpi

Enkeleitä pyhiä, Palveaisi henkiä.

Oi, sit' laiva kulkeepi, Kohten kottoo soutaapi, Lippu liehuu valkoinen, Se on monen karvainen,

Tulinen ja punainen, On kuin tähti kultainen, Laivan päällä paistaapi, Yli maitten näyttääpi.

Kaikki sitä katsovat, Kansat kaikki vuattivat, Kuin on sota hankkijois, Rakkauten vartiois.

Veljet veisaat sisässä, Kaljahtelloot henkessä, Hyppäilevat iloist viel, A sisaretki kaikki siel,

Soittaat, ilost huutavat, Rakkautest houraavat, On kuin täällä ajassa, Kuninkaamme laivassa.

Väliajoin ilossa, Väliajoin murheessa, Kons on päivät pimiät, Silloin ajat pitemmät,
Asks He the sailors, Asks He these brethren, Who are commanding the ship, Who are recruiting the warship:

"Brethren, what are you afraid of, When you are hastening on the sea?

Stay in holy peace, Cause I am with you in the war!"

Then He gives an order, In disarray there fly

Holy angels,

Praying spirits.

$\mathrm{Oh}$, then the ship passes on, Rows straight towards home, The white flag is fluttering, It has many colours,

Feverish and red,

Twinkling like a golden star, Shining on the warship, It is seen over the lands.

Everybody is looking at it, All the peoples are watching it, How the war is risen, How love is guarded.

Brethren are singing the hymns inside, They are shouting in spirit, Jumping yet for joy, And sisters are also there,

Playing, shouting for joy,

Raving from love, They are like in worldliness, In the ship of our King.

Sometimes in joy

Sometimes in sorrow, When the days are dark, Then the times are miserable. 
Vaan jos aurinko paistaapi, Valonsa meil jakkaapi, Sitten sieluin iloitsee, Henkein ratki riemuitsee.

Vaikka yhtä pitämme, Ilois-vaivois kiitämme,

Sen myö vissist tietämme, Kun merellä riennämme.

Siellä vaivat vastustaat, murhen päivät kohtajaat, Kons on ilmat tuuliset, Silloin ajat suruiset.

Kuitenki se iloittaa, Se se minua lohtuttaa, Ett on laivan sisällä, Valittu on Isältä.

Puhun viellä veisussa Lasten sota laivasta, Henkellises venheessä Puhun Herran henkessä:

Jotk' ei tässä laivassa, Ole kanssain vaivoissa, Sil ei osa taivaassa, Autuviiten ilossa.

Se jo nähti etellä, Kuin oli Nooan aikanna, Jotk' ei arkin sisässä, Ne kaik hukkuit vetessä.

Jotka näitä kirjoitti, Sille Henki ilmoitti, Pyhä Henki puheli, Salaisesti saneli.
But when the sun is shining, Sharing with us its light, Then my soul rejoices, My spirit is enjoying.

Although we all congregate, Praying the Lord in our joy and sorrow,

We know that all conceivably, When we hasten on the worldly sea.

There we meet with hardships, There we face the days of sorrow, When the weather is windy, Then the times are woeful.

However it delights me, This does not console me, That I am inside the ship, That I am chosen by the Father.

I'll tell more in my hymn About the children's warship, In this spiritual boat I'll tell in the Lord's spirit:

Who are not in that ship, Who are not with us in hardships, Those will not share the place in heaven, In the joy of the blessed ones.

All this was seen in the past, How it was in the times of Noah, Who were not inside the ark, All of them died in water.

Who wrote these lines, To him the Spirit appeared, The Holy Ghost addressed, Secretly He said. 
Amen, Jessut kiitämme, Sinua kunnijoitamme tääl ja iänkaikkisest, Amen, sanon totisest.
Amen, we praise Jesus, We adore You Here and eternally, Amen, I say faithfully.

EFA, AK 526, 149-154 (71), ERA DV 275, 6 [0:27:02-0:37:11]. 